\title{
Potensi Fraksinasi Sarang Semut Papua (Myrmecodia pendans) pada Penurunan TNF- $\alpha$ dan Perbaikan Secara Histopatologi Kartilago Osteoartritis Lutut Kelinci
}

\author{
Nucki Nursjamsi Hidajat, Dicky Mulyadi, Fachry A. Tandjung, Asep Sulaeman \\ Departemen Orthopaedi dan Traumatologi Fakultas Kedokteran Universitas Padjadjaran \\ Rumah Sakit Dr. Hasan Sadikin Bandung, Indonesia
}

\begin{abstract}
Abstrak
Reaksi seluler kondrosit osteoartritis pada lutut ditandai dengan peningkatan sitokin tumor necrosis factor- $\alpha$ (TNF- $\alpha$ ).TNF- $\alpha$ mengaktifkan fibroblas dan makrofag sinovial untuk menyekresi enzim degradasi dan menekan sintesis proteoglikan rawan sendi sehingga memberikan gambaran histopatologik kartilago yang mengalami perubahan. Osteoartritis sekunder terjadi akibat trauma sendi yang menyebabkan nyeri. Terapi obat seperti non-steroidal anti-inflammatory drugs (NSAIDs) yang digunakan menyebabkan efek samping merugikan jika digunakan dalam jangka panjang. Fraksinasi sarang semut papua (Myrmecodia pendans) diketahui memiliki kandungan salah satunya flavonoid yang berfungsi sebagai anti-inflamasi, antioksidan dan pelindung sel. Berdasar hal tersebut maka ingin diketahui potensi fraksinasi sarang semut papua pada osteoartritis kartilago lutut kelinci dalam menghambat enzim proinflamasi, yaitu TNF- $\alpha$ dan memberikan perbaikan secara histopatologik dibanding dengan kontrol. Penelitian menggunakan uji eksperimental hewan dengan desain experimental comparative menggunakan 8 kelinci ras New Zealand yang dibagi menjadi 2 kelompok, yaitu kelompok kontrol dan kelompok yang diberikan fraksinasi sarang semut papua dengan dosis 2,5 mg/kgBB intra-artikular. Kemudian dilakukan pengukuran kadar TNF- $\alpha$ dan skoring secara histopatologik. Penelitian dilakukan di Fakultas Kedokteran, Universitas Padjadjaran periode Februari-Maret 2017. Pada Uji-t tidak berpasangan untuk TNF- $\alpha$ didapatkan nilai $\mathrm{p}=0,011$; Uji Mann Whitney untuk skoring histopatologik dengan nilai $\mathrm{p}=0,034$ pada kelompok yang diberian fraksinasi sarang semut papua. Terdapat penurunan TNF- $\alpha$ dan perbaikan secara histopatologik pada kartilago osteoartritis lutut kelinci yang diberikan fraksinasi sarang semut papua.
\end{abstract}

Kata kunci: Fraksinasi sarang semut sapua, osteoartritis, TNF- $\alpha$

\section{Potential of Fractionated Papuan Ant Nest (Myrmecodia Pendans) to Decrease TNF- $\alpha$ and Improve Osteoarthritis Cartilage Histopathological Features in Rabbits Knee}

\begin{abstract}
Condrocyte cellular reaction in knee with osteoarthritis is characterized by increased tumor necrosis factor- $\alpha$ (TNF- $\alpha$ ) cytokine level. TNF- $\alpha$ activates fibroblasts and synovial macrophages to secrete degradation enzymes and supress cartilage proteoglycan synthesis, leading to histopathological changes in cartilages. Secondary osteoarthritis is triggered by a joint trauma that leads to pain. Long term drug therapy, such as non-steroidal antiinflammatory drugs (NSAIDs), will lead to adverse effects. Fractionated Papuan ant nest (Myrmecodia Pendans) is known as containing flavonoid that plays a role as anti-inflamatory agent, antioxidang, and cell protector. This study aimed to identify the potential of fractionated Papuan ant nest to inhibit pro-inflamatory enzyme, i.e. TNF- $\alpha$, and improve the histopathological features in rabbit knee cartilage with osteoarthritis. This was a comparative animal experiment on 8 New Zeland rabbits that were divided into 2 groups: control group and treatment group conducted at the Faculty of Medicine, Universitas Padjadjaran, in February-March 2017. The treatment group received $2.5 \mathrm{~mm} / \mathrm{kgBW}$ fractionated Papuan ant nest as treatment. Measurement was then performed on TNF- $\alpha$ level and histopathological scoring. Statitical analysis was performed using unpaired t-test for TNF- $\alpha$ and Mann Whitney test for histopathological scoring. The results showed that the p-values for TNF- $\alpha$ and histopathological scoring were 0.011 and 0.034 , respectively, in the group receiving fractionated Papuan ant nest. Reduction of TNF- $\alpha$ level and histopathological improvement are found in rabbit knee cartilage with arthritis when fractionated Papuan ant nest is given.
\end{abstract}

Key words: Fractionated Papuan ant nest, osteoarthritis, TNF- $\alpha$.

Korespondensi: Dr. Nucki N. Hidajat, dr., Sp.OT(K), M.Kes, Departemen Orthopaedi dan Traumatologi Fakultas Kedokteran Universitas Padjadjaran/Rumah Sakit Dr. Hasan Sadikin, Jalan Pasteur No. 38 Bandung, Email: nuckinhidajat@gmail.com 


\section{Pendahuluan}

Osteoartritis merupakan penyakit persendian yang kasusnya paling umum ditemukan di dunia. Osteoartritis diklasifikasikan menjadi 2 tipe, yaitu $\mathrm{OA}$ primer dan $\mathrm{OA}$ sekunder. $\mathrm{OA}$ primer adalah suatu penyakit degeneratif dan OA sekunder muncul lebih awal, sering kali penyebabnya antara lain trauma atau obesitas yang berlebihan. ${ }^{1}$ Data yang terbaru dari Global Burden of Disease (GBD 2013), diperkirakan 242 juta jiwa manusia di dunia yang menderita ostearthritis mengalami keluhan nyeri dan terbatas aktivitasnya, tercatat sekitar 13 juta jiwa hidup bertahun-tahun dengan kecatatan. ${ }^{2}$

Mekanisme awal terjadinya osteoartritis sekunder ialah kerusakan pada kartilago normal oleh trauma fisik yang dapat berupa trauma tunggal besar atau trauma kecil berulang. Dengan demikian, secara biomolekuler terjadi perubahan bentuk dari reaksi seluler kondrosit yang ditandai dengan peningkatan sitokin proinflamasi, seperti tumor necrosis factor- $\alpha$ (TNF- $\alpha$ ). TNF- $\alpha$ ini mengaktifkan fibroblas sinovial, makrofag sinovial, dan juga kondrosit untuk menyekresi enzim degradasi, yaitu MMPs yang dapat mendegradasi jaringan lunak dan pembentukan pannus serta menekan sintesis proteoglikan rawan sendi sehingga pada osteoartritis gambaran secara histopatologiknya akan mengalami perubahan. ${ }^{3}$

Nyeri merupakan keluhan yang tersering ditemukan pada pasien osteoartritis. Terapi obat seperti non-steroidal anti-inflammatory drugs (NSAIDs) sering dipergunakan untuk mengatasi keluhan tersebut. Namun, NSAIDs sering menyebabkan efek samping merugikan jika digunakan dalam jangka panjang dengan dosis $1.200 \mathrm{mg} /$ hari. $^{4}$ Oleh karena efek yang merugikan tersebut, maka peneliti berupaya mengembangkan penatalaksanaan osteoartritis tanpa menimbulkan efek yang membahayakan bagi pasien yang antara lain adalah penggunaan sarang semut papua (Myrmecodia Pendans). Fraksinasi sarang semut papua yang berfungsi sebagai anti-inflamasi dan juga antioksidan diharapkan akan mampu menghambat sitokin proinflamasi, yaitu TNF- $\alpha$ serta fungsinya sebagai pelindung sel yang dapat memberikan perbaikan secara histopatologik pada kartilago osteoartritis lutut kelinci. ${ }^{5}$

\section{Metode}

Desain penelitian yang digunakan pada penelitian ini adalah uji eksperimental hewan dengan metode experimental comparative. Penelitian dilakukan di Laboratorium Farmakologi Klinik dan Laboratorium Patologi Anatomi Fakultas Kedokteran Universitas Padjadjaran periode Februari-Maret 2017 dan telah mendapatkan sertifikat etik dari Komite Etik Penelitian Universitas Padjadjaran Bandung (No: LB.04.01/ A05/EC/039/II/2017). Sebanyak 16 ekor kelinci ras New Zealand diperoleh dari peternakan Asep Rabbit di Lembang yang dipergunakan sebagai hewan coba dalam penelitian ini. Kriteria inklusi yang digunakan ialah sehat, dewasa muda ras New Zealand, usia 24 bulan, bobot 3.000 gram, dan tidak pernah dipergunakan sebagai hewan coba pada penelitian lain. Dilakukan karantina terlebih dahulu selama 7 hari untuk adaptasi terhadap lingkungan tempat tinggal baru sebelum penelitian dilakukan dan semua hewan coba ditempatkan dalam kandang yang berbentuk sama dan pakan yang sama, Hewan coba kelinci tersebut dikelompokkan secara acak menjadi 2 kelompok (masing-masing terdiri atas 8 ekor kelinci), kelompok kontrol dan kelompok yang diberikan fraksinasi sarang semut papua.

Hewan coba kelinci dibuat dalam keadaan sedasi dengan pemberian ketamin dengan cara intramuskular sebanyak $1 \mathrm{cc}$, kemudian dilakukan perlakuan cedera mengenai satu sendi lutut yang berperan sebagai weight bearing dengan langkah-langkah sebagai berikut: (1) Pencukuran sendi lutut (sendi yang berperan sebagai weight bearing). (2) Tindakan aseptik dan antiseptik dengan alkohol $70 \%$ dan povidone iodine 10\%. (3) Perlakuan dengan merusak ACL (anterior cruciate ligament) dan meniskus lutut kelinci dengan cara membuat sayatan kulit ukuran $2 \mathrm{~cm}$ dengan posisi lutut kelinci fleksi. (4) Pemutusan ACL dan merusak meniskus dengan menggunakan pisau ukuran No. 11 pada ACL dan meniskus. (5) Penjahitan luka dan dilakukan pemeliharaan luka serta perlakuan kaki kelinci batas ruang gerak dipelihara dalam kandang (Gambar 1).

Pada akhir minggu ke-3 dari setiap kelinci tersebut diambil bahan pemeriksaan melalui 2 sumber, yaitu cairan sinovium dari tempat cedera pada sendi lutut kelinci sebanyak $1 \mathrm{cc}$ yang diperiksakan ke bagian Patologi Klinik FK Unpad RSUP Dr. Hasan Sadikin Bandung untuk dilakukan pemeriksaan TNF- $\alpha$ dan kartilago dari tempat cedera lutut kelinci diambil dengan ukuran $1 \mathrm{~mm}$ x $1 \mathrm{~mm}$ untuk diperiksa ke bagian Patologi Anatomi FK Unpad RSUP Hasan Sadikin Bandung dengan pewarnaan hematoksilin-eosin (HE). 


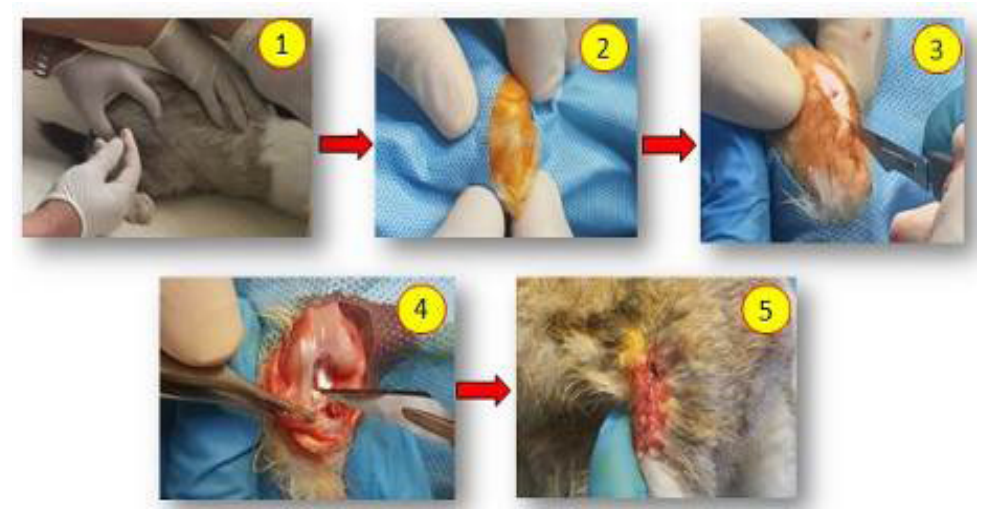

\section{Gambar 1 Pembuatan Hewan Coba Osteoartitis Lutut Kelinci}

(1) Pencukuran sendi lutut; (2) Tindakan aseptik dan antiseptik; (3) Perusakan anterior cruciate ligament (ACL) dan menikus lutut; (4) Pemutusan ACL dan merusak meniskus; (5) Penjahitan dan pemeliharaan luka. (Penjelasan prosedur pada Bab Metode)

Fraksinasi sarang semut papua didapatkan dari Laboratorium MIPA Universitas Padjadjaran melalui tahapan proses ektraksi sebelumnya. Akhir minggu ke-6 secara bersamaan setelah pengambilan sampel, lalu dilanjutkan dengan pemberian fraksinasi sarang semut papua dosis 2,5 mg/kgBB intra-artikuler. Kelompok pertama dinamakan kelompok kontrol, yaitu kelompok yang tidak diberikan fraksinasi sarang semut papua dan kelompok kedua ialah kelompok yang diberikan fraksinasi sarang semut papua.

Uji statistikdigunakan untuk membandingkan rerata variabel numerik antara pre dan pasca perlakuan maka analisis dilakukan dengan uji-t berpasangan apabila data berdistribusi normal dan alternatif Uji Wilcoxon apabila data tidak berdistribusi normal. Kemudian, untuk dapat membandingkan variabel kategorik antara sebelum dan sesudah perlakuan dipergunakan Uji McNemar. Adapun kriteria kemaknaan hasil uji statistik yang digunakan adalah nilai $\mathrm{p}$ apabila $p \leq 0,05$ signifikan atau bermakna secara statistika, dan $p>0,05$ tidak signifikan atau tidak bermakna secara statistik. Data yang diperoleh dicatat dalam formulir khusus kemudian diolah melalui program SPSS versi 21.0 for windows.

Evaluasi histopatologi yang dipakai berkaitan dengan inflamasi yang terjadi pada osteoartritis menurut Haywood L dkk. ${ }^{13}$ Osteoartritis and Cartilage 25 dengan pewarnaan hematoxylin dan eosin (H\&E) secara histologis dinilai berdasar atas skala berikut:

$0=$ normal (lapisan $<4$ sel sinovial, distribusi seluler jarang, dengan sedikit atau tidak ada sel inflamasi)

1=peradangan ringan (lapisan 4 atau 5 sel sinovial, peningkatan selularitas dengan beberapa sel inflamasi)

$2=$ peradangan moderat (lapisan 6 atau 7 sel sinovial, selular padat dengan sel inflamasi, tetapi tidak ada agregat limfoid)

$3=$ peradangan berat (lapisan $>7$ sel sinovial, selular padat dan infiltrasi sel inflamasi, mungkin mengandung agregat limfoid perivaskular).

\section{Hasil}

Didapatkan bahwa pada kelompok kontrol terjadi peningkatan kadar TNF- $\alpha$ sebesar 9,14

Tabel 1 Perbandingan Perubahan TNF- $\alpha$ pada Kartilago OA Lutut Kelinci yang Diberikan Fraksinasi Sarang Semut Papua dengan yang Tidak Diberikan Fraksinasi Sarang Semut Papua

\begin{tabular}{|c|c|c|c|c|}
\hline \multirow{2}{*}{ Kelompok } & \multicolumn{2}{|c|}{ Waktu Pengamatan } & \multirow{2}{*}{ Perubahan } & \multirow{2}{*}{ Nilai p } \\
\hline & Sebelum & Setelah & & \\
\hline Kontrol & $37,57(7,23)$ & $46,71(6,3)$ & $9,14(3,41)$ & $0,000127^{* *}$ \\
\hline Fraksinasi & $41,29(4,18)$ & $36.63(5,5)$ & $-4,65(3.86)$ & 0,011 \\
\hline
\end{tabular}

Keterangan: nilai disajikan dalam rata-rata dan simpangan baku ; nilai p diperoleh dari uji t dua kelompok tidak berpasangan, ${ }^{*}$ ) perubahan bermakna jika $\mathrm{p}<0,05,{ }^{* *}$ ) sangat bermakna jika $\mathrm{p}<0,01$ 
Tabel 2 Analisis Perbandingan Gambaran Histopatologis Kartilago OA Lutut Kelinci yang Diberikan Fraksinasi SSP dengan yang Tidak diberikan Fraksinasi Sarang Semut Papua

\begin{tabular}{lccc}
\hline Waktu Pengamatan & \multicolumn{2}{c}{ Perlakuan } & p-value \\
\cline { 2 - 3 } & $\begin{array}{c}\text { Fraksinasi } \\
(\mathbf{n}=7)\end{array}$ & $\begin{array}{c}\text { Kontrol } \\
(\mathbf{n}=7)\end{array}$ & - \\
\hline Sebelum perlakuan & 3 & 3 & $0,442^{\mathrm{a}}$ \\
$\quad$ Median & $3-3$ & $2-3$ & \\
$\quad \begin{array}{l}\text { Range } \\
\text { Setelah perlakuan }\end{array}$ & & & $0,038^{\mathrm{a}^{*}}$ \\
$\quad$ Median & 2 & 3 & \\
$\quad$ Range & $1-3$ & $3-3$ & \\
Nilai p & $0,034^{\mathrm{b}^{*}}$ & $0,157^{\mathrm{b}}$ & \\
\hline
\end{tabular}

Keterangan: Nilai p diperoleh dari : a) Uji Mann Whitney, b) Uji Wilcoxon, * ) perbedaan/perubahan bermakna jika $\mathrm{p}<0,05,{ }^{* *}$ ) sangat bermakna jika $\mathrm{p}<0,01$

ng/L menjadi 46,71 ng/L dari sebelumnya 37,57 ng/L dan peningkatan ini dinyatakan sangat bermakna (nilai $\mathrm{p}=0,000127$ ). Sementara itu pada kelompok dengan pemberian fraksinasi terjadi penurunan kadar TNF- $\alpha$ sebesar 4,65 ng/L menjadi 36,63 ng/L dari sebelumnya 41,29 $\mathrm{ng} / \mathrm{L}$, dan penurunan ini dinyatakan bermakna dengan nilai $\mathrm{p}=0,011$ (Tabel 1 ).

Skor histopatologik dari median 3 (inflamasi berat) sesudah kelinci diberikan perlakuan osteoartritis, untuk kelompok yang diberikan fraksinasi terjadi perbaikan menjadi median 2 (inflamasi sedang) dan dinyatakan dari hasil Uji Wilcoxon diperoleh nilai p 0,034 sehingga disimpulkan bahwa pada kelompok kelinci yang diberikan fraksinasi sarang semut papua menyebabkan penurunan histopatologik yang bermakna. Sementara itu, pada kelompok kontrol, nilai median histopatologik tidak terjadi perubahan baik pada akhir minggu ke-3 maupun pada akhir minggu ke- 6 atau akhir penelitian dengan nilai yang masih tetap dalam kondisi inflamasi berat (median 3), dan dinyatakan tidak mengalami perubahan bermakna dengan nilai nilai $\mathrm{p}=0,157$ (Tabel 2).

\section{Pembahasan}

Mekanisme terjadi osteoartritis sekunder antara lain karena kerusakan pada kartilago normal oleh trauma fisik. Trauma dapat pula terjadi karena tindakan operasi yang meliputi operasi kartilago sendi, ligamen, dan meniskus. Perubahan awal ditandai dengan penurunan matriks kartilago yang mengakibatkan pelemahan struktur sendi.

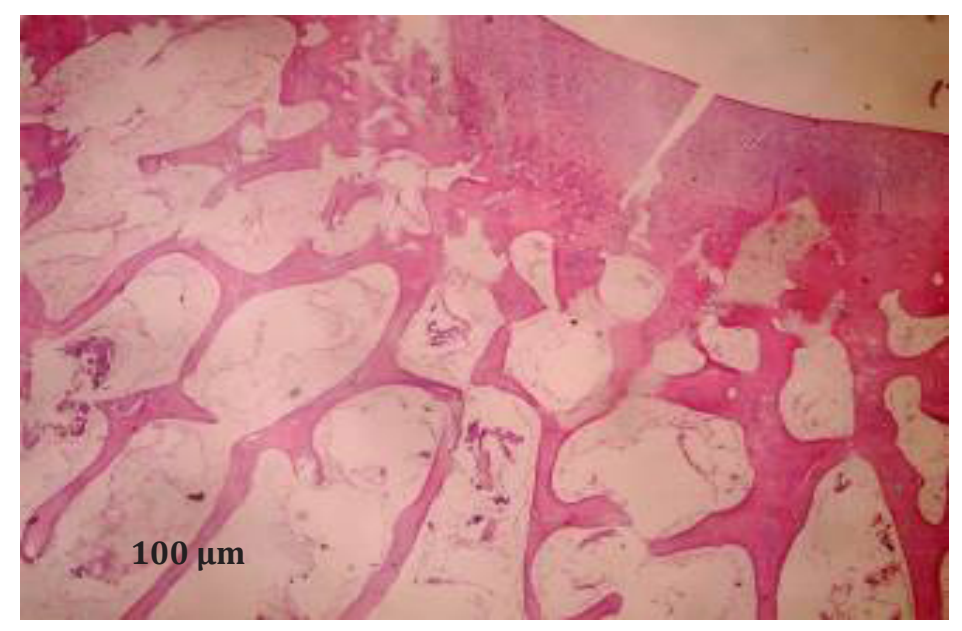

Gambar 2 Gambaran Histologi Kartilago Lutut Kelinci Normal dengan Pembesaran 40x 


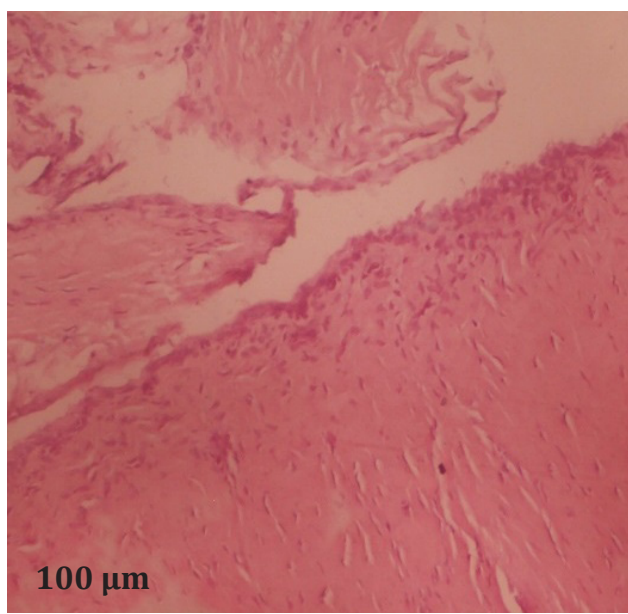

Peradangan berat dengan pembesaran 40x

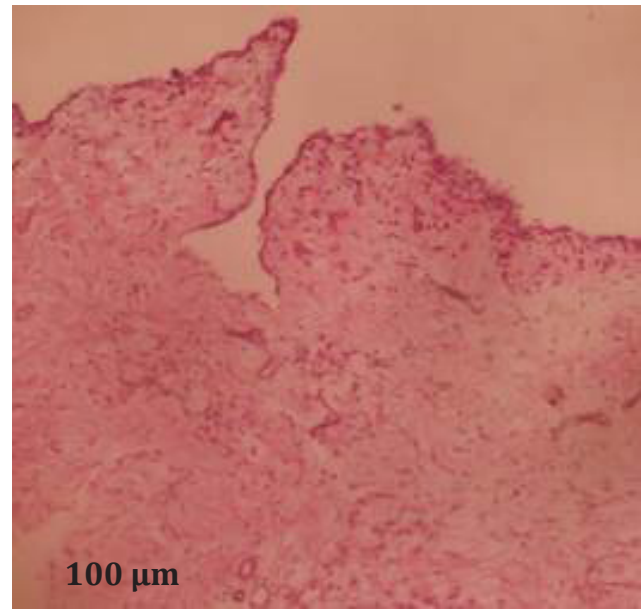

Peradangan sedang dengan pembesaran 40x

\section{Gambar 3 Perubahan Gambaran Histopatologi Peradangan Berat Menjadi Sedang pada Kartilago Lutut Kelinci}

Artikuler kartilago juga dapat rusak akibat proses inflamasi, proses inflamasi yang terjadi pada hewan coba kelinci dengan memutus ACL dan merusak meniskus lutut kelinci. Salah satu sitokin proinflamasi yang paling dikenal ialah TNF- $\alpha$. Sitokin perusak ini dihasilkan oleh makrofag di samping sel-sel lain pada sinovium dan jumlahnya meningkat terutama pada stadium dini osteoartritis. Diketahui bahwa TNF- $\alpha$ merupakan sitokin sentral pada patogenesis osteoartritis.

Penurunan TNF- $\alpha$ pada proses awal terjadinya osteoartritis pada lutut kelinci dapat dipengaruhi oleh fraksinasi dari sarang semut

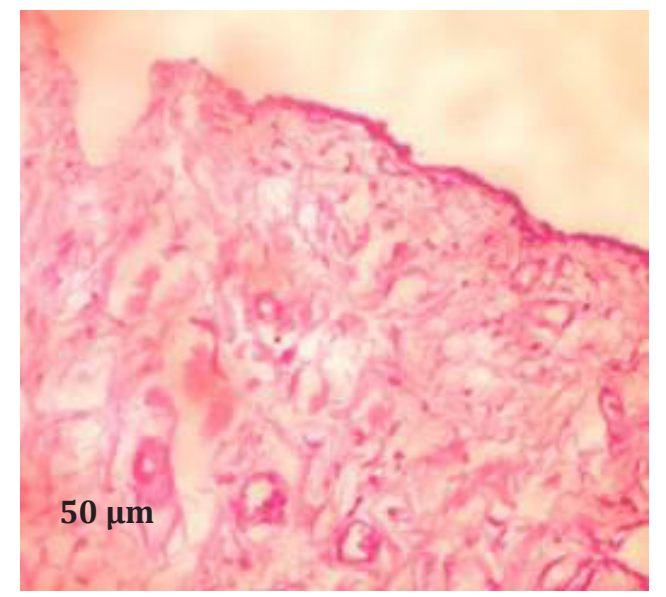

Peradangan sedang dengan pembesaran 100x papua. Bahan aktif darihasil fraksinasi sarang semut papua salah satunya adalah flavonoid. Flavonoid berperan sebagai anti inflamasi, anti oksidan dan berfungsi sebagai pelindung sel. Fungsi anti-inflamasi serta pelindung sel dari pemberian fraksinasi sarang semut papua dapat menghambat enzim proinflamasi, yaitu TNF- $\alpha$ dan fungsinya sebagai pelindung sel secara histopatologis akan memberikan perbaikan pada kartilago osteoartritis lutut kelinci.

Penelitian ini mempergunakan Histo-score sebagai alat ukur penilaian hasil histopatologik kartilago sendi lutut pascacedera memutus ACL dan merusak meniskus. Histo-score memakai

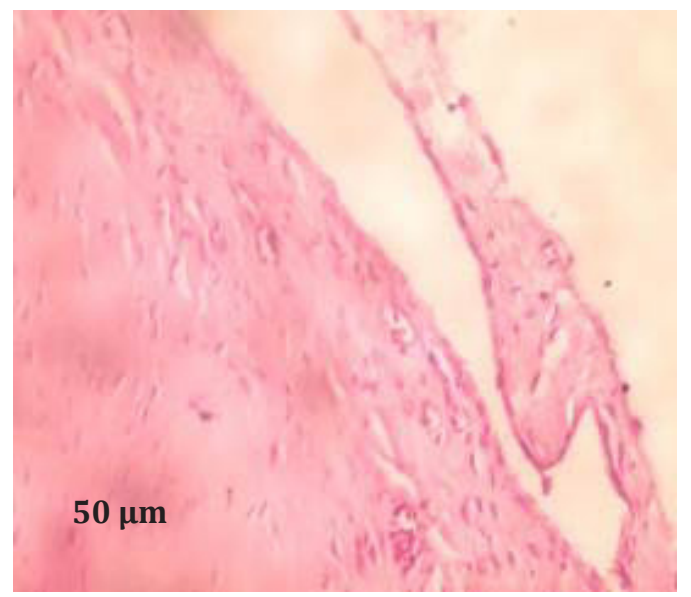

Peradangan ringan dengan pembesaran 100x

\section{Gambar 4 Perubahan Gambaran Histopatologi Dari Peradangan Sedang Menjadi Ringan pada Kartilago Lutut Kelinci}


nilai inflamasi dan seluleritas kartilago sendi lutut dan dihitung secara statistik. Kadar TNF- $\alpha$ pada kelompok kontrol pada akhir perlakuan minggu ke-6 terjadi peningkatan sebesar 9,14 ng/L, sedangkan pada kelompok pemberian fraksinasi sarang semut papua terjadi penurunan kadar TNF- $\alpha$ sebesar $4,65 \mathrm{ng} / \mathrm{L}$ dan perbedaan ini dinyatakan sangat bermakna $(p=0,0000026)$. Sementara itu, skor histopatologik kelompok kontrol pada akhir perlakuan minggu ke-6 mengalami peningkatan dengan nilai $\mathrm{p}=0,442$, namun pada kelompok pemberian fraksinasi sarang semut papua terjadi perbaikan yang bermakna dengan nilai $\mathrm{p}=0,038$.

Berdasar atas hal tersebut maka dapat disimpulkan bahwa pemberian fraksinasi sarang semut papua secara intraartikuler pada kelinci yang telah diberikan perlakuan osteoartritis dengan memutus ACL dan merusak meniskus terbukti efektif untuk dapat menurunkan nilai TNF- $\alpha$ dan secara histopatologik memberikan perbaikan pada kartilago osteoartritis lutut kelinci. Keadaan ini sesuai dengan penelitian yang dilakukan pada tahun 2012 bahwa flavonoid punya peranan dalam osteoartritis sebagai antiinflamasi dan pelindung sel dengan dosis 10, 20, dan $30 \mu \mathrm{g} / \mathrm{mL}$ dapat menurunkan sitokin proinflamasi, yaitu interleukin 1 pada kartilago OA lutut kelinci. ${ }^{14}$ Namun, perlu dilakukan penelitian lebih lanjut pada manusia sebelum temuan ini diaplikasikan secara luas untuk membantu dalam penghambatan proses terjadi osteoartritis. Perlu dilakukan penelitian lanjutan juga pada tahap akhir dari fraksinasi, yaitu isolasi dalam hal ini flavonoid dari sarang semut papua dan pengaruhnya pada sitokin proinflamasi dan perubahannya secara histopatologi pada lutut osteoartritis.

\section{Daftar Pustaka}

1. MJ Islam, MA Yusuf, MS Hossain, M Ahmed. Update management of osteoartritis: a review. J Sci Foundation. 2013;11(2):174955.

2. Vos T, Barber RM, Bell B, Bertozzi-Villa A, Biryukuv S, Bolliger I, dkk. Global, regional, and national incidence, prevalence, and years lived with disability for 301 acute and chronic diseases and injuries in 188 countries, 1990-2013: a systematic analysis for the Global Burden of Disease Study 2013. Lancet. 2015;386:73:1323-30.

3. Kohn MD, Sassoon AA, Fernando ND. Classifications in brief: Kellgren-Lawrence classification of osteoarthritis. Clin Orthop Relat Res. 201;474(8):1886-93.

4. National Institute for Health and Care Excellence (NICE). Non-steroidal antiinflammatory drugs. Manchester: NICE; 2013. [Diakses September 2013]. Tersedia dari: www.nice.org.uk.

5. Harun A, Suryani A, Armyn, Supriatno, Singgih MF. Anti-Cancer Activity Ant Nest Flavonoid Fractionation Test (Myrmecodia Pendans).IOSR Journal of Dental and Medical Sciences. 2014;13(6):1-6.

6. Andriyasa K, Putra TR. Korelasi antara derajat beratnya osteoartritis lutut dan cartilage oligomeric matrix protein serum. Jurnal Penyakit Dalam. 2012;13(1):10-20.

7. Pelletier JP, Martel-Pelletier J, Abramson SB. Osteoartritis, an inflammatory disease: potential implication for the selection of new therapeutic targets. Arthritis Rheum. Arthritis Rheum. 2001;44(6):1237-47.

8. Muir S. Evidence based exercise prescription for older adults witrh knee osteoartritis. Exercise and Physical Activity in Aging Conference: Blending Research and Practice"; American Physical Therapy Association Section on Geriatrics, Indianapolis, Indiana, USA; 2010. hlm. 28-31.

9. King KL, March L, Anandacoomarasamy A. Obesity and osteoartritis. Indian J Med Res. 2013;138(2):185-93.

10. Musumeci, G. The effect of mechanical loading on articular cartilage. J Funct Morphol Kinesiol. 2016;1(2):154-61.

11. Soeksmanto A, Subroto MA, Wijaya $H$, Simanjuntak P. Anticancer activity test for extracts of sarang semut plant (Myrmecodya pendens) to HeLa and MCM-B2 cells. Pak J Biol Sci. 2010;13(3):148-51.

12. Harun A, Suryani A, Armyn, Supriatno, Singgih MF. Anti-Cancer Activity Ant Nest Flavonoid Fractionation Test (Myrmecodia Pendans).IOSR Journal of Dental and Medical Sciences. 2014;13(6):1-6.

13. Haywood L, McWilliams DF, Pearson CI, Gill SE, Ganesan A, Wilson D, dkk. Inflammation and angiogenesis in osteoarthritis. Arthritis Rheum. 2017;48(8):2173-7 .

14. Pei L, Zheng L, Bai Y. Effect of aralia echiocaulis hand mass flavonoids against oxidative damage and inflammatory of osteoartritis cartilage cells. Beijing, China: Minzu University of China, State Nationalities Affairs Commission and Department of Educational Key Lab of Minority Traditional Medicine; 2012. 


\title{
Pilihan dan Persepsi Risiko terhadap Jenis Sumber Air Minum pada Masyarakat Kumuh Perkotaan di Bantaran Sungai Cikapundung Kota Bandung
}

\author{
Sri Yusnita Irda Sari, Ardini Raksanagara \\ Departemen Ilmu Kesehatan Masyarakat \\ Fakultas Kedokteran Universitas Padjadjaran Bandung, Indonesia
}

\begin{abstract}
Abstrak
Sistem penyaluran air di wilayah kumuh perkotaan sangat terbatas dan tidak dapat diandalkan baik kuantitas dan kualitas terutama di negara-negara berkembang. Pilihan terhadap jenis sumber air dan tipe pengolahan akan berdampak pada status kesehatan masyarakat. Penelitian ini bermaksud menggali hubungan faktor demografi dan persepsi risiko terhadap pilihan sumber air minum pada masyarakat kumuh perkotaan. Studi potong lintang dilaksanakan pada bulan September-Oktober 2015 pada masyarakat kumuh perkotaan di 20 RW yang berada di bantaran sungai Cikapundung Kota Bandung. Sampel dipilih dengan metode acak sistematis. Data dikumpulkan melalui kuesioner dan kualitas sampel air minum diperiksa dengan Suncoli test kit untuk mendeteksi dan menghitung jumlah bakteri Coliform. Jenis air minum yang dikonsumsi masyarakat kumuh perkotaan adalah merebus air minum yang bersumber air sumur dan air perpipaan atau membeli air minum dalam kemasan. Faktor yang berhubungan dengan pilihan jenis air minum yang dikonsumsi adalah faktor status ekonomi, ketersediaan jenis sumber air bersih yang dimiliki, dan faktor pendidikan kepala keluarga $(p<0,001)$. Persepsi terhadap risiko keamanan sumber air bersih berhubungan dengan pilihan jenis sumber air minum yang dikonsumsi $(p<0,001)$. Upaya promosi kesehatan mengenai cara pengolahan air minum perlu ditingkatkan dan perbaikan penyediaan air perpipaan harus diupayakan.
\end{abstract}

Kata kunci: Air minum, masyarakat kumuh, perkotaan, persepsi risiko

\section{Choice and Risk Perception on Drinking Water source among Urban Slum Dwellers Living on Cikapundung River Basin in Bandung City}

\begin{abstract}
s
Water supply system in urban slum area is often unreliable in terms of water quality and quantity, particularly in developing countries. Choices on the type of water source and water treatment may be associated with public health outcomes. This study aimed to investigate correlation between demographic factors and risk perception on the choice of water source type in urban slum area. A cross-sectional study was conducted during September-October 2015 in 20 neigborhood (Rukun Warga, RW) living on Cikapundung river basin in Bandung City. Households were sampled using systematic random sampling method. Data were collected through a questionnaire and water quality was assessed using Suncoli test kit to examine total Coliform level in drinking water. Drinking water consumed by the urban slum dweller included boiled water from ground well and piped water as well as commercial drinking water. Factors influencing the choice of drinking water were economic status, availability of clean water source, and education level of head of household $(\mathrm{p}<0.001)$. Perception towards health risks carried by clean water correlates with the choice of drinking water to be consumed $(p<0.001)$. Health promotion efforts on how to process drinking water need to be improved and piped water provision should be improved.
\end{abstract}

Key words: Drinking water, risk perception, slum dweller, urban

Korespondensi: Dr. Sri Yusnita Irda Sari, dr., MSc, Departemen Ilmu Kesehatan Masyarakat Fakultas Kedokteran Universitas Padjadjaran, Jalan Eyckman No.38 Bandung,Email: italatif@yahoo.com, sri.yusnita@unpad.ac.id 